\title{
Pengaruh Pemberian Pupuk Organik Cair (POC) Nasi Basi Terhadap Pertumbuhan dan Hasil Tanaman Sawi (Brassica juncea L) Pada Tanah Podsolik Merah Kuning
}

\author{
Syarif Nizar Kartana dan Kurniati \\ Fakultas Pertanian Universitas Kapuas Sintang \\ Email : nizarngael21@gmail.com
}

\begin{abstract}
Abstrak: Penelitian ini bertujuan untuk mengetahui peranan pupuk organik cair dari nasi basi dalam meningkatkan pertumbuhan dan hasil tanaman sawi pada tanah podsolik merah kuning. Penelitian ini dilaksanakan di Desa Jerora 1 Kecamatan Sintang Kabupaten Sintang dari bulan Februari sampai April 2020. Hasil penelitian menunjukkan bahwa pemberian pupuk organik cair dari nasi basi dapat meningkatkan pertumbuhan dan hasil tanaman sawi pada tanah podsolik merah kuning. Perlakuan terbaik dalam penelitian ini diperoleh pada pemberian pupuk organic cair dari nasi basi sebanyak $200 \mathrm{ml} /$ liter air dengan rerata jumlah daun pertanaman sebanyak 8,10 helai dan rerata berat segar pertanaman seberat 43,19 gram.
\end{abstract}

Kata Kunci: POC Nasi Basi, Pertumbuhan, Hasil, Sawi, Podsolik Merah Kuning

\section{PENDAHULUAN}

Sawi (Brassica juncea.L) merupakan tanaman sayuran yang mengandung vitamin dan mineral yang mempunyai nilai ekonomis yang tinggi yaitu dalam $100 \mathrm{~g}$ sawi nilai gizinya adalah sebagai berikut: protein, lemak, karbohidrat, $\mathrm{Ca}, \mathrm{P}, \mathrm{Fe}, \mathrm{Vitamin}$ A,Vitamin B,dan Vitamin C. Di Indonesia tanaman sawi merupakan jenis sayuran yang mempunyai nilai ekonomi tinggi dan digemari banyak orang ,namun produksinya masih tergolong rendah. (Manurung,2011).

Berdasarkan data Badan Statistik (2016), produksi keseluruhan tanaman sawi di Kalimantan Barat yaitu rata-rata 7,02 ton/ha per tahun. Produksi sawi di Kabupaten Sintang masih rendah yaitu produksi rata-rata 3,57 ton/ha per tahun. Produksi ini masih rendah bila dibandingkan dengan produksi pad yang baik, yang menghasilkan antara 10-30 ton/ ha (Edi dan Bobiheo, 2013).

Menurut Badan Pusat Statistik Kabupaten Sintang (2016), Luas tanah PMK mencapai 0,93 juta/ha di Kabupaten Sintang, Peningkatan produksi tanaman sawi di Kabupaten Sintang menghadapi kendala, karena sebagian besar jenis tanah yang tersedia adalah tanah PMK.

Salah satu usaha yang dapat dilakukan untuk memperbaiki kandungan unsur hara dan bahan organik pada tanah PMK adalah dengan memberikan Pupuk Organik Cair (POC) yang berasal dari nasi basi. Selama ini masyarakat masih belum memanfaatkan POC dari nasi basi ini meskipun memiliki potensi kandungan unsur hara dan kandungan bahan organik yang cukup baik.. Menurut Litbag Pertanian Sulawesi Utara (2012) pupuk organik cair nasi basi mengandung $\mathrm{C}$ Organik 2,65 \%, N/total 0,16\%, P/total 0,29\%, K/ total 0,23\% dan $\mathrm{C} / \mathrm{N}$ rasio 16,56 dengan $\mathrm{PH} 5,58$.

Penelitian ini bertujuan untuk mengetahui peranan Pupuk Organik Cair (POC) dari nasi basi dalam meningkatkan pertumbuhan dan hasil tanaman sawi pada tanah Podsolik Merah Kuning (PMK)

\section{METODOLOGI PENELITIAN}

Penelitian ini dilaksanakan Di Desa Jerora 1 Kabupaten Sintang. Penelitian dilaksanakan mulai bulan Februari sampai April 2020. Penelitian ini menggunakan metode percobaan lapangan dengan rancangan acak kelompok (RAK) terdiri atas 5 perlakuan, masing-masing diulang 5 kali. Lima perlakuan yang dimaksud adalah: $\mathrm{N}_{0}$ : tanpa pupuk organik cair nasi basi; $\mathrm{N}_{1}$ : pupuk organik cair nasi basi $50 \mathrm{ml} /$ liter air; $\mathrm{N}_{2}$ : pupuk organik cair nasi basi $100 \mathrm{ml} /$ liter air; $\mathrm{N}_{3}$ : pupuk organik cair nasi basi $150 \mathrm{ml} /$ liter air; $\mathrm{N}_{4}$ : pupuk organik cair nasi basi $200 \mathrm{ml} /$ liter air. Alat dan bahan yang digunakan dalam penelitian ini adalah: Cangkul, meteran, kamera, kalkulator, gembor, timbangan, alat tulis, gunting, benih sawi, furadan, POC nasi basi, air dan tanah PMK.

Tahapan dalam penelitian ini adalah persiapan lahan, penyemaian benih sawi, pembuatan POC nasi basi, penanaman, pemberian POC nasi basi, pemeliharaan tanaman dan panen.

PIPER No. 31 Volume 16 Oktober 2020 


\section{Pengaruh Pemberian Pupuk Organik Cair (POC) Nasi Basi Terhadap Pertumbuhan dan Hasil Tanaman Sawi (Brassica juncea L) Pada Tanah Podsolik Merah Kuning}

Data yang diamati dalam penelitian ini adalah jumlah daun dan berat segar tanaman sawi. Data yang diperoleh selanjutnya akan dianalisis dengan

\section{HASIL DAN PEMBAHASAN}

\section{Hasil Penelitian}

\section{Jumlah Daun}

Pengamtan terhadap jumlah daun dilakukan pada saat tanaman sawi telah siap dipanen dengan cara menghitung seluru daun yang telah terbentuk. Rerata hasil pengamatan terhadap jumlah daun dapat dilihat pada Tabel 1 berikut :

Tabel 1. Rerata pengamatan jumlah daun

\begin{tabular}{|c|c|c|c|c|c|c|c|}
\hline \multirow[t]{2}{*}{ Pertakuan } & \multirow[b]{2}{*}{ I } & \multicolumn{4}{|c|}{ Utangan } & \multicolumn{2}{|c|}{ Jumtah Rerata } \\
\hline & & II & III & I & & V & \\
\hline $\mathrm{N}_{0}$ & 5,25 & 5,50 & 5,50 & 6,25 & 5,25 & 27,75 & 5,55 \\
\hline $\mathrm{N}_{1}^{0}$ & 7,00 & 5,75 & 5,25 & 5,75 & 5,25 & 29,00 & 5,80 \\
\hline $\mathrm{N}_{2}$ & 5,75 & 6,75 & 6,00 & 6,50 & 6,00 & 31,00 & 6,20 \\
\hline $\mathrm{N}_{3}^{2}$ & 9,00 & 8,00 & 6,75 & 8,00 & 7,00 & 38,75 & 7,75 \\
\hline $\mathrm{N}_{4}^{3}$ & 8,25 & 8,50 & 7,75 & 8,50 & 7,50 & 40,50 & 8,10 \\
\hline Jumlah & 35,25 & 34,50 & 31,25 & 35,00 & 31,00 & 167,00 & 6,68 \\
\hline
\end{tabular}

Sumber : Hasil Pengamatan, 2020.

Data hasil pengamatan tersebut selanjutnya dianalisa dengan menggunakan Analisa Sidik Ragam yang disajikan pada tabel 2 berikut :

Tabel 2. Analisis sidik ragam pengaruh pemberian POC nasi basi terhadap jumlah daun

\begin{tabular}{lcccccc}
\hline SK & DB & JK & KT & F Hitung & \multicolumn{2}{c}{ F Tabel } \\
& & & & & 0,05 & 0,01 \\
\hline Kelompok & 4 & 31,51 & 0,87 & $3,55^{*}$ & 3,01 & 4,77 \\
Perlakuan & 4 & 27,21 & 6,80 & $2 /, 48^{* *}$ & 3,01 & $4, / /$ \\
Galat & 16 & 3,96 & 0,24 & & \\
\hline Total & 24 & 34,69 & & $\mathrm{kk}=7,44 \%$ & & \\
\hline
\end{tabular}

Keterangan : ns $=$ Tidak berpengaruh

$$
\begin{aligned}
& *=\text { Berpengaruh nyata } \\
& * *=\text { Berpengaruh sangat nyata }
\end{aligned}
$$

Hasil analisis sidik ragam menunjukkan bahwa pemberian POC Nasi Basi berpengaruh sangat nyata terhadap peningkatan jumlah daun tanaman sawi, maka dilakukan Uji BNJ yang disajikan pada tabel 3 berikut:

\begin{tabular}{|c|c|c|c|c|c|}
\hline Perlakuan & & Selis & & & \\
\hline $\mathrm{N}_{0}$ & $5,55 \mathrm{a}$ & & & & \\
\hline $\mathrm{N}_{1}^{0}$ & $5,80 \mathrm{ab}$ & $0,25^{\mathrm{ns}}$ & & & \\
\hline $\mathrm{N}_{2}$ & $6,20 \mathrm{~b}$ & $0,65 * *$ & $0,40^{\mathrm{ns}}$ & & \\
\hline $\mathrm{N}_{3}^{2}$ & $7,75 \mathrm{c}$ & $2,55 * *$ & $2,30 * *$ & $1,90^{* *}$ & \\
\hline $\mathrm{N}_{4}$ & $8,10 \mathrm{c}$ & $2,20 * *$ & $1,95 * *$ & $1,55^{* *}$ & $0,35^{\mathrm{ns}}$ \\
\hline $\mathrm{SE}=0,10$ & & \multicolumn{3}{|c|}{$\begin{array}{l}\text { BNJ } 0,05=0,43083 \\
\text { BNJ } 0,01=0,546248\end{array}$} & \\
\hline \multicolumn{3}{|c|}{ Sumber : Data hasil penelitian, 2020} & \multirow{2}{*}{\multicolumn{3}{|c|}{$\begin{array}{l}\text { Keterangan : Angka yang ditandai huruf } \\
\text { yang sama adalah tidak beda nyata }\end{array}$}} \\
\hline \multicolumn{3}{|c|}{ PIPER No. 31 Volume 16 Oktober 2020} & & & \\
\hline
\end{tabular}

Tabel 3. Uji BNJ Pengaruh POC nasi basi terhadap jumlah daun (helai) 


\section{Pengaruh Pemberian Pupuk Organik Cair (POC) Nasi Basi Terhadap Pertumbuhan dan Hasil Tanaman Sawi (Brassica juncea L) Pada Tanah Podsolik Merah Kuning}

Hasil uji BNJ menunjukkan bahwa pemberian POC nasi basi sebanyak $200 \mathrm{ml} /$ liter air menghasilkan rerata jumlah daun yang lebih banyak dari perlakuan lainnya yaitu 8,10 helai sedangkan tanaman sawi yang tidak diberikan pupuk organik cair dari nasi basi menghasilkan jumlah daun yang terendah dengan rerata sebanyak 5,55 helai.

\section{Berat Segar Tanaman}

Penimbangan berat segar tanaman sawi dilakukan pada saat akhir penelitian dengan menggunakan timbangan analitik. Rerata hasil pengamatan terhadap berat segar tanaman dapat dilihat pada Tabel 4 berikut :

Tabel 4. Rerata pengamatan berat segar tanaman (gram)

\begin{tabular}{|c|c|c|c|c|c|c|c|}
\hline \multirow[t]{2}{*}{ Perlakuan } & \multicolumn{5}{|c|}{ Ulangan } & Jumlah & Rerata \\
\hline & I & II & III & IV & V & & \\
\hline $\mathrm{N}_{0}$ & 16,25 & 22,25 & 27,00 & 19,25 & 16,50 & 101,25 & 20,25 \\
\hline $\mathrm{N}_{1}$ & 20,50 & 21,25 & 21,75 & 25,00 & 23,50 & 112,00 & 22,40 \\
\hline $\mathrm{N}_{2}$ & 27,00 & 25,00 & 25,00 & 30,50 & 25,50 & 132,50 & 26,50 \\
\hline $\mathrm{N}_{3}$ & 25,25 & 30,15 & 35,25 & 34,00 & 35,50 & 159,65 & 31,93 \\
\hline $\mathrm{N}_{4}$ & 42,25 & 43,35 & 43,55 & 42,35 & 44,45 & 215,95 & 43,19 \\
\hline Jumlah & 131,25 & 142,00 & 152,55 & 151,10 & 144,45 & 721,35 & 28,85 \\
\hline
\end{tabular}

Sumber : Hasil pengamatan, 2020

Data hasil pengamatan tersebut selanjutnya dianalisa dengan menggunakan Analisa Sidik Ragam yang disajikan pada tabel 5 berikut :

Tabel.5. Analisis sidik ragam pengaruh POC nasi basi terhadap berat segar tanaman

\begin{tabular}{llccccc}
\hline SK & DB & JK & KT & F Hitung & \multicolumn{2}{c}{ F Tabel } \\
& & & & & 0,05 & 0,01 \\
\hline Kelompok & 4 & 57,98 & 14,49 & $0,10^{\text {ns }}$ & 3,01 & 4,77 \\
Perlakuan & 4 & 16,03 & 42,25 & $49,87 * *$ & 3,01 & 4,77 \\
Galat & 16 & 13,82 & 8,42 & & & \\
\hline Total & 24 & 18,84 & \multicolumn{3}{c}{$\mathrm{kk}=5,40 \%$} \\
\hline
\end{tabular}

Keterangan : ns $=$ Tidak berpengaruh

$$
\begin{aligned}
& *=\text { Berpengaruh nyata } \\
& * *=\text { Berpengaruh sangat nyata }
\end{aligned}
$$

Hasil analisis sidik ragam menunjukkan bahwa pemberian POC Nasi Basi berpengaruh tanaman sawi, maka dilakukan Uji BNJ yang disajikan pada tabel 6 berikut : sangat nyata terhadap peningkatan berat segar

Tabel 6 Uji BNJ Pengaruh POC nasi basi terhadap berat segar tanaman (gram)

\begin{tabular}{|c|c|c|c|c|c|}
\hline Perlakuan & Rerata & & Selisih & & \\
\hline $\begin{array}{l}\mathrm{N}_{0} \\
\mathrm{~N}_{1} \\
\mathrm{~N}_{2} \\
\mathrm{~N}_{3} \\
\mathrm{~N}_{4}^{3}\end{array}$ & $\begin{array}{l}20,25 \mathrm{a} \\
22,40 \mathrm{a} \\
26,50 \mathrm{~b} \\
31,93 \mathrm{c} \\
43,19 \mathrm{~d}\end{array}$ & $\begin{array}{c}2,00^{\mathrm{ns}} \\
6,25^{* *} \\
12,88^{* *} \\
22,94^{* *}\end{array}$ & $\begin{array}{c}4,00 * * \\
10,73 * * \\
20,79 * *\end{array}$ & $\begin{array}{c}6,63 * * \\
16,69 * *\end{array}$ & $10,06 * *$ \\
\hline $\mathrm{SE}=0,58$ & & $\begin{array}{r}\text { BNJ } 0 \\
\text { BN }\end{array}$ & $\begin{array}{l}=2,51 \\
, 01=3,18\end{array}$ & & \\
\hline
\end{tabular}

Sumber : Data hasil penelitian, 2020

Keterangan :

Angka yang ditandai huruf yang sama adalah

tidak beda nyata

PIPER No. 31 Volume 16 Oktober 2020 


\section{Pengaruh Pemberian Pupuk Organik Cair (POC) Nasi Basi Terhadap Pertumbuhan dan Hasil Tanaman Sawi (Brassica juncea L) Pada Tanah Podsolik Merah Kuning}

Hasil Uji BNJ menunjukkan bahwa pemberian POC nasi basi sebanyak $200 \mathrm{ml} / \mathrm{liter}$ air menghasilkan rerata berat segar tanaman sawi yang lebih baik daripada perlakuan lainnya yaitu 43,19 gram sedangkan tanaman sawi yang tidak diberikan pupuk organik cair dari nasi basi menghasilkan rerata berat segar terendah yaitu seberat 20,25 gram.

\section{Pembahasan}

Hasil penelitian menunjukkan bahwa pemberian POC nasi basi dapat meningkatkan pertumbuhan dan hasil tanaman sawi yang ditandai dengan meningkatnya jumlah daun serta berat segar tanaman sawi. Peningkatan ini terjadi karena kandungan unsur hara yang terdapat dalam POC nasi basi telah mampu menyediakan unsur hara bagi tanaman sawi. Unsur hara yang terkandung di dalamnya berbentuk larutan yang sangat cair sehingga sangat mudah diserap oleh tanaman, sekalipun oleh bagian daun atau batangnya. POC nasi basi ini diperoleh dari proses fermentasi substrat organik berupa nasi basi yang melibatkan kerja mikroorganisme lokal. (Nasaruddin dan Rosmawati, 2011). Hasil uji laboratorium menunjukkan kandungan unsur hara makro pada pupuk organik cair nasi basi yang digunakan dalam penelitian ini adalah $\mathrm{N}=$ $3,19 \%, \mathrm{P} 2 \mathrm{O} 5=1,64 \% \mathrm{~K} 2 \mathrm{O}=0,43 \%$ (PT SDK Batu Buil, 2020) Fungsi Nitrogen untuk tanaman sayuran yaitu sebagai penyusun protein, untuk pertumbuhan pucuk tanaman dan menyuburkan pertumbuhan vegetatif sehingga sesuai untuk tanaman sayuran daun seperti sawi Phospor berperan sebagai salah satu unsur penyusun protein, dibutuhkan untuk pembentukan bunga, buah dan biji, merangsang pertumbuhan akar menjadi memanjang dan tumbuh kuat sehingga tanaman akan tahan kekeringan. Kalium berperan dalam proses metabolisme seperti fotosintesis dan respirasi yang merupakan hal penting dalam pertumbuhan.(Sutejo dan Masriah 2007:12).

Hasil penelitian juga menunjukkan bahwa semakin besar dosis ataujumlah pupuk organik cair nasi basi yang digunakan maka semakin tinggi jumlah daun dan berat segar tanaman sawi. Hal ini disebabkan karena jenis tanah yang digunakan dalam penelitian ini adalah tanah Podsolik Merah Kuning yang memang memiliki kandungan unsur hara dan bahan organik yang sangat rendah. Salah satu prinsip dalam pemupukan yang kita kenal adalah tepat dosis. Tepat dosis artinya jumlah pupuk yang diberikan harus sesuai dengan status hara tanah dan kebutuhan tanaman. Seperti yang kita ketahui bahwa tanah PMK memiliki kandungan unsur hara dan bahan organik yang rendah sehingga untuk mencapai pertumbuhan dan hasil tanaman sawi yang tinggi dapat dicapai pada taraf jumlah poc nasi basi yang tertinggi dalam penelitian ini yatu $200 \mathrm{ml} /$ liter air. Kandungan unsur hara makro yang relatif rendah pada poc nasi basi juga menyebabkan kebutuhan akan jumlah pupuk yang diberikan juga semakin besar untuk memperoleh pertumbuhan dan hasil tertinggi dalam penelitian ini.

\section{KESIMPULAN}

Hasil penelitian menunjukkan bahwa pemberian pupuk organik cair dari nasi basi dapat meningkatkan pertumbuhan dan hasil tanaman sawi pada tanah podsolik merah kuning. Pemberian pupuk organic cair dari nasi basi sebanyak $200 \mathrm{ml} /$ liter air menghasilkan rerata jumlah daun tertinggi yaitu sebanyak 8,10 helai serta rerata berat segar tanaman tertinggi yaitu seberat 43,19 gram.

\section{SARAN}

Pupuk organik cair dari nasi basi dapat digunakan oleh masyarakat dalam upaya untuk meningkatkan produktifitas tanaman sawi pada tanah padsolik merah kuning dengan pemberian sebanyak $200 \mathrm{ml} / \mathrm{liter}$ air.

\section{DAFTAR PUSTAKA}

BPS Kabupaten Sintang. 2016. Kabupaten

Sintang Dalam Angka. Sintang: Badan

Pusat Statistik Kabupaten Sintang.

Gesperez, V. 1999). Metode Rancangan. Bandung: Armico.

Harjoso. 2013. Pemanfaatan Tanah Podzolik Merah Kuning melalui Pemberian Pupuk Kandang kotoran burung walet.Diakses pada tanggal 25 November 2017. 
Pengaruh Pemberian Pupuk Organik Cair (POC) Nasi Basi Terhadap Pertumbuhan dan Hasil Tanaman Sawi (Brassica juncea L) Pada Tanah Podsolik Merah Kuning

Heyne, K. (2014:105). Tumbuhan Berguna Indonesia. Jilid I dan II. Terj.Badan Libang . Cetakan I. Koperasi karyawan jakarta. Diakses pada tanggal 16 Desember 2017.

Manurung,.2011.Respon Pertumbuhan dan Produksi tanaman sawi (Brasisca juncea L.) Terhadap penggunaan Pupuk Organik Cair. Skripsi. Universitas Sumatra Utara.

Sutejo.(2002:22) dalam Dora Fatma Nurshanti. Menyatakan bahwa Pengaruh Pemberian Pupuk Organik cair Terhadap Pertumbuhan dan Hasil Tanaman Sawi Hijau (Brassica Juncea L.). Diakses pada tanggal 4 Agustus 2018.
Nasaruddin, \& Rosmawati. (2011). Pengaruh pupuk organik cair (POC) hasil fermentasi daun gamal, batang pisang dan sabut kelapaterhadap pertumbuhan bibit kakao. Jurnal Agrisistem, 7(1), 29-37.

Suprihatin, (2010). Teknologi fermentasi. Surabaya: UNESA University Press.

Rahmah, N. (2011). Studi pemanfaatan limbah cair tahu untuk pupuk cair tanaman (StudiKasus Pabrik Tahu Kenjeran). Surabaya:Teknik Lingkungan ITS 